\title{
Career perspective: John W. Severinghaus
}

\author{
John W Severinghaus
}

\begin{abstract}
After training in physics during World War II, I spent 2 years designing radar at Massachusetts Institute of Technology and then switched to biophysics. After medical school and a residency, I was doctor drafted to National Institutes of Health where I studied blood gas transport in hypothermia and developed the carbon dioxide electrode and the blood gas analyzer $\left(\mathrm{pH}\right.$, partial pressure of $\mathrm{O}_{2}$, and partial pressure of $\left.\mathrm{CO}_{2}\right)$. I joined the University of California San Francisco in 1958 in a new anesthesia department and new Cardiovascular Research Institute. My research aims were anesthesia patient monitoring, respiratory physiology, blood gas transport, and high-altitude acclimatization and pathology.
\end{abstract}

Keywords: Anesthesia, Monitor, Altitude, Acclimatization, Regulation of respiration, Cerebral blood flow, Blood gas analysis, Oxygen dissociation curve, $\mathrm{CO}_{2}$ electrode, Oximetry

\section{Text}

I arrived foot-first under chloroform in 1922 in Madison, WI, USA. Judged to be not academic, I built a boat, a desk I still have, radios, and hi-fi for classical music. As a Physics major during World War II, I was draft-deferred to work on radar at Massachusetts Institute of Technology. After the atom bomb was dropped, I switched to apply my knowledge on physics to medicine. During medical school (P\&S 1949), I built electrophrenic respirators for several anesthesia departments [1]. Robert Dripps (University of Pennsylvania anesthesia chief) recruited me to anesthesia that needed my electronic skills. I persuaded my coresident Peter Safar to test, on me, a small dose (20 mg) of the newly arrived succinyl choline. I had 2 min of unexpected apnea. I measured and published the uptake rate of $\mathrm{N}_{2} \mathrm{O}$ during anesthesia in willing patients [2]. I spent a year with Julius Comroe and Robert Forster at Pennsylvenia testing carotid chemoreceptor pharmacology and measuring lung dead space.

In 1953, to satisfy the doctor draft, I joined the US Public Health Service (USPHS) and became chief of anesthesia research at the National Institutes of Health $(\mathrm{NIH})$ in Bethesda. I doubted a paper that said carbon dioxide $\left(\mathrm{CO}_{2}\right)$ excretion was blocked during human surgical hypothermia. I disproved it by measuring blood $\mathrm{PCO}_{2}$ at patient temperature using Van Slyke's manometric apparatus and a homemade temperature-controlled $\mathrm{pH}$ analyzer. In the

Correspondence: jwseps@comcast.net

University of California San Francisco, San Francisco, CA 94607, USA process, I accurately determined temperature coefficients of blood gases that became standards [3].

In 1953, at the American Physiological Society (APS) fall meeting, I heard Richard Stow (Ohio State Med) describes a $\mathrm{PCO}_{2}$ electrode he invented. It measured $\mathrm{pH}$ in a film of distilled water under a rubber membrane exposed to blood. He found its drift prevented calibration. I stabilized it by adding soda $\left(\mathrm{NaHCO}_{3}\right)$. This StowSeveringhaus $\mathrm{CO}_{2}$ electrode is now part of all blood gas analyzers. In 1957, I combined it with Leland Clark's polarographic $\mathrm{O}_{2}$ electrode in a thermostat bath making the first blood gas analyzer $\left(\mathrm{pH}\right.$, partial pressure of $\mathrm{CO}_{2}$ $\left(\mathrm{PCO}_{2}\right)$, and partial pressure of $\mathrm{O}_{2}\left(\mathrm{PO}_{2}\right)$ ) [4] (Figure 1), now in the Smithsonian museum.

I finished anesthesia residency at the University of Iowa with Stuart Cullen in 1957 (on leave from NIH). During the APS fall meeting that year, also in Iowa City, Comroe, newly appointed chair of a new University of California San Francisco (UCSF) Cardiovascular Research Institute, persuaded me to join him. I agreed instantly after he persuaded the chief of surgery at UCSF, by phone, to offer Stuart Cullen the chair of Anesthesia in a new independent (of surgery) department. Cullen and I arrived in mid-1958. I settled with family of six in my present home in Ross. I taught anesthesia (in the operating rooms) once a week, plus night call, and established labs to study respiratory physiology with Robert Mitchell and anesthesia with Ted Eger, both continuing as colleagues throughout my career. 
By 1961, during a 6-week visit of Hans Loeschcke (Goettingen), Mitchell located the brain's ventral medullary cerebrospinal fluid (CSF) $\mathrm{pH}$ sensors, the $\mathrm{PCO}_{2}$ chemoreceptors [5]. This led us to study, in ourselves, the role of CSF $\mathrm{pH}$ and bicarbonate in acclimatization to high altitude at the UC White Mt (CA) laboratories, a range east of the Sierra Nevada [6]. We later studied the control of cerebral blood flow (CBF) at altitude, also in each other, joined by Tom Hornbein [7] soon after his ascent of Everest by the West Ridge. We repeated these acclimatization studies in Peruvian high-altitude natives at the invitation of Alberto Hurtado [8]. In 1966, Cedric Bainton and I showed that Peruvian altiplano natives have much lower (than normal) peripheral chemoreceptor (carotid body) response to hypoxia [9]. We showed that CBF was not elevated in high-altitude natives in Bolivia and fell well below normal on oxygen [10]. With many others, we tried to find the mechanisms of highaltitude pulmonary and cerebral edema. $\mathrm{Xu}$ and I reported increased brain tissue vascular endothelial growth factor in acutely hypoxic rats, a possible cause of capillary leakage [11].

I developed physical instrumentation useful in hypothermic anesthesia, beginning at the NIH with a batteryoperated monitor of esophageal breath sounds, temperature, and electrocardiography for use with explosive anesthetics (e.g., cyclopropane) [12]. In the late 1970s, Gerry Ozanne, Bill Young, and I developed centralized monitoring of anesthetic and respiratory gas concentrations using mass spectrometry [13]. Long nylon catheters brought airway gas from the airway of patients in each of 10 (and later 20) operating rooms. The gas in them was rapidly sampled sequentially, providing data to each anesthesiologist on a computer screen about once a minute. Two firms commercially installed these systems in about 400 institutions. They became obsolete about 1995 when cheaper 'stand-alone' infrared

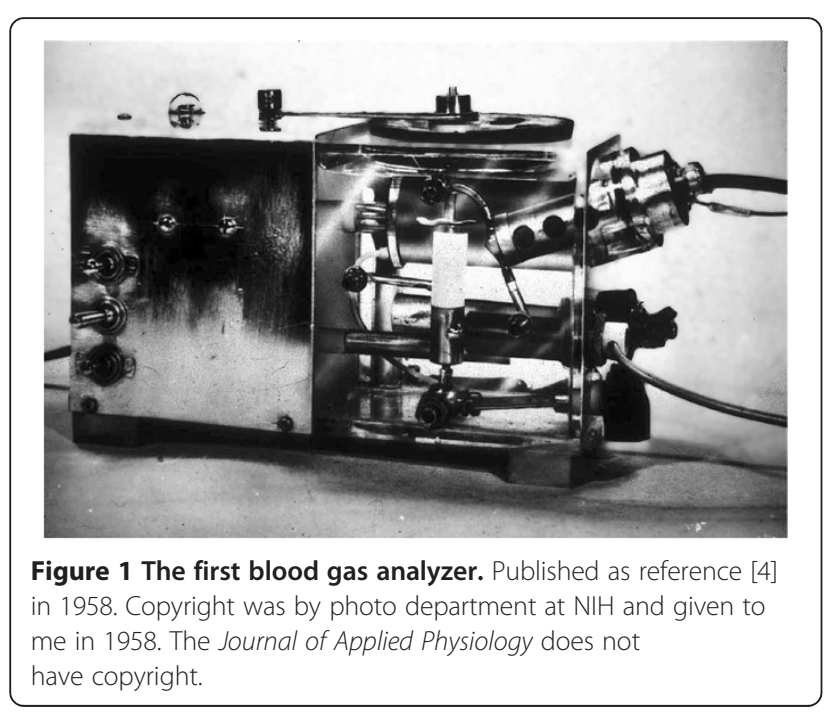

capnographic type monitors were developed. After Young moved to New York, he kept watching our OR data via the Arpanet (before the Internet). One day, he phoned me, worried that in OR5 the patient's $\mathrm{PCO}_{2}$ was 80 Torr. The attending was shocked to be seen (in New York) just trying to get his paralyzed patient to breathe (shades of today's spying).

During a sabbatical in Copenhagen, Niels Lassen and I showed that $\mathrm{CBF}$ is determined by brain arteriolar, not tissue, $\mathrm{PCO}_{2}$. As a subject in that study, while placing a needle in my internal jugular bulb, Lassen suddenly paralyzed my right face and tongue that lasted 3 days.

I devised a blood gas slide rule for solving the effects of $\mathrm{pH}$ and temperature on $\mathrm{O}_{2}$ dissociation and on acidbase balance [14]. It was made and distributed for many years by Radiometer, the early developer of automated blood gas analyzers. To improve accuracy of the slide rule, F.J.W. Roughton from Cambridge joined Freeman Bradley (my technician for 30 years) and me using his ingenious method to very accurately measure slight desaturation at the top of the standard human oxygen dissociation curve (ODC) [15]. Our work became the standard human ODC, and I found a simple accurate equation of the ODC [16].

Other monitoring methods included the first transcutaneous combined $\mathrm{PO}_{2}-\mathrm{PCO}_{2}$ electrode [17]. We established a laboratory for testing the accuracy of pulse oximeters at

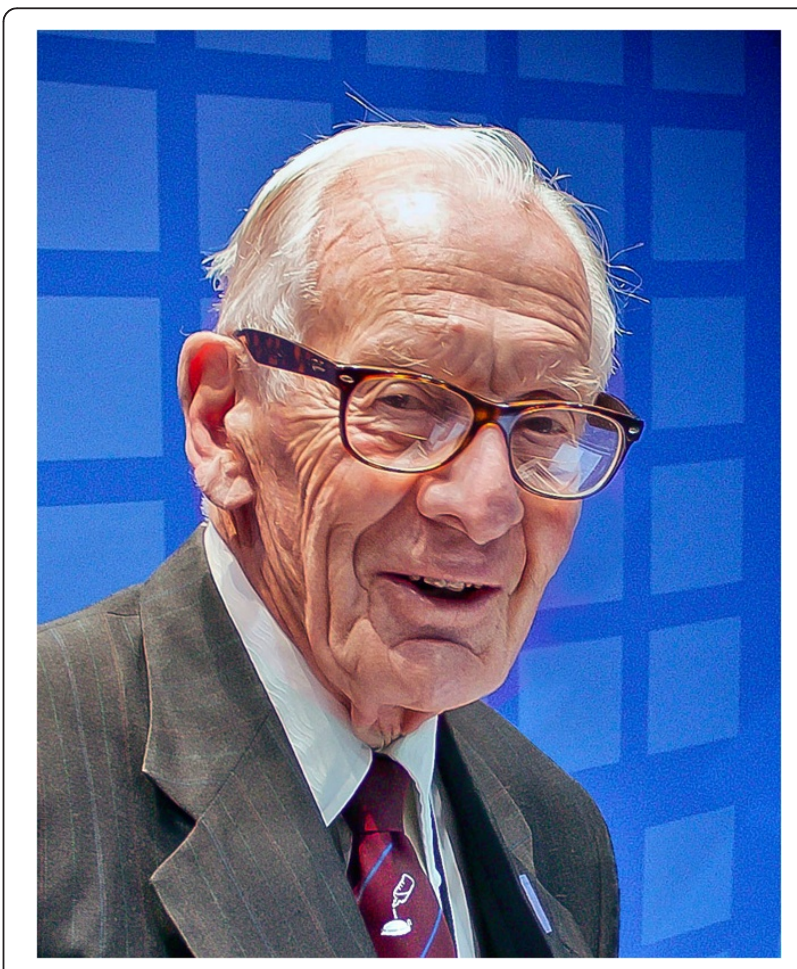

Figure 2 Portrait, 2011 given to me by Sara Cheng from the University of Colorado. No copyright. 
low $\mathrm{O}_{2}$ saturation in volunteers, which is still in use to provide manufacturers with data for the FDA [18]. My career tended toward history when I joined Poul Astrup in writing the history of blood gases and acid-base balance [19] and then the history of pulse oximetry [20].

\section{Honors}

I received the first American Society of Anesthesiologists (ASA) Award for Excellence in Research (1986), presented the first ASA annual John W Severinghaus Translational Science Lecture, and received an honorary degree Dr. Med. HC from the Universities of Copenhagen (1979) and Uppsala (2008).

I continue to teach UCSF residents the history and status of physical chemistry, acid-base balance, blood gas analysis, altitude acclimatization, and the discoveries of eight scientists who contributed to the discovery of oxygen and the pulmonary circulation. For the last 11 years, I have reviewed the world literature on altitude for each quarterly issue of the Journal of High Altitude Medicine and Biology, edited by John West.

For my other community activity, I served for 7 years on the Marin Healthcare District Board, owner of Marin General Hospital. As chair, I helped the board settle a lawsuit to recover local control. I am proud to be a liberal Democrat, an atheist Unitarian, and an active member of several medical organizations advocating Single Payer Healthcare for All. My wife Elinor and I have four children and soon will celebrate our 65th anniversary.

If I started all over again and worked harder, I probably would have been less useful to the world of medicine. I loved my work. In my father's words, 'Work is my recreation' (Figure 2).

\footnotetext{
Abbreviations

ASA: American Society of Anesthesiologists; APS: American Physiological Society; CBF: Cerebral blood flow; $\mathrm{CO}_{2}$ : Carbon dioxide; CSF: Cerebrospinal fluid; CVRI: Cardiovascular Research Institute; NIH: National Institutes of Health; ODC: Oxygen dissociation curve; $\mathrm{PCO}_{2}$ : Partial pressure of $\mathrm{CO}_{2}$; $\mathrm{PO}_{2}$ : Partial pressure of $\mathrm{O}_{2}$; UCSF: University of California San Francisco; USPHS: US Public Health Service.
}

\section{Competing interests}

The author declares that he has no competing interests.

\section{Acknowledgements}

My most important paper was "Electrodes for blood $\mathrm{pO}_{2}$ and $\mathrm{pCO}_{2}$ determination." The following are the teachers and colleagues who influenced me most (all medical doctors): Virginia Apgar, Poul Astrup, Julius H. Comroe, Stuart C. Cullen, Robert D. Dripps, Edmund I. Eger, II, Thomas Hornbein, Robert H. Mitchell, and Elmer L. Severinghaus (father)

Received: 15 August 2013 Accepted: 12 September 2013

Published: 07 Oct 2013

\section{References}

1. Severinghaus JW: Electrophrenic respirator: description of portable allelectronic apparatus. Anesthesiology 1951, 12:123-128.

2. Severinghaus JW: Rate of uptake of nitrous oxide in man. J Clin Invest 1954, 33:1183-1189.
3. Severinghaus JW, Stupfel MA, Bradley AF Jr: Accuracy of blood pH and $\mathrm{PcO}_{2}$ determinations. J App/ Physiol 1956, 9:189-196.

4. Severinghaus JW, Bradley AF Jr: Electrodes for blood $\mathrm{pO}_{2}$ and $\mathrm{pCO}_{2}$ determination. J Appl Physiol 1958, 13:515-520.

5. Mitchell RA, Loeschcke HH, Massion WH, Severinghaus JW: Respiratory responses mediated through superficial chemosensitive areas on the medulla. J Appl Physiol 1963, 18:523-533.

6. Severinghaus JW, Mitchell RA, Richardson BW, Singer MM: Respiratory control at high altitude suggesting active transport regulation of CSF pH. J Appl Physiol 1963, 18:1155-1166.

7. Severinghaus JW, Chiodi H, Eger El II, Brandstater BB, Hornbein TF: Cerebral blood flow in man at high altitude. Circ Res 1966, 19:274-282.

8. Severinghaus JW, A Carcelen B: Cerebrospinal fluid in man native to high altitude. J Appl Physiol 1964, 19:319-321.

9. Severinghaus JW, Bainton $C R$, Carcelen A: Respiratory insensitivity to hypoxia in chronically hypoxic man. Resp Physiol 1966, 1:308-334.

10. Sørensen SC, Lassen NA, Severinghaus JW, Coudert J, Paz-Zamora MP: Cerebral glucose metabolism and cerebral blood flow in high altitude residents. J Appl Physiol 1974, 37:305-310.

11. Xu FP, Severinghaus JW: Rat brain VEGF expression in alveolar hypoxia: possible role in high-altitude cerebral edema. J Appl Physiol 2002, 85:53-57.

12. Severinghaus JW: The telecor: an esophageal probe monitoring device. Anesthesiology 1957, 18:145-149.

13. Ozanne GM, Young WG, Mazzie WJ, Severinghaus JW: Multipatient anesthetic mass spectrometry: rapid analysis of data stored in long catheters. Anesthesiology 1981, 55:62-70.

14. Severinghaus JW: Blood gas calculator. J Appl Physiol 1966, 21:1108-1116.

15. Roughton FJW, Severinghaus JW: Accurate determination of $\mathrm{O}_{2}$ dissociation curve of human blood above $98.7 \%$ saturation with data on $\mathrm{O}_{2}$ solubility in unmodified human blood from $0^{\circ}$ to $37^{\circ} \mathrm{C}$. J Appl Physiol 1973, 35:861-869.

16. Severinghaus JW: Simple, accurate equations for human blood $\mathrm{O}_{2}$ dissociation computations. J Appl Physiol: Respirat Environ Exercise Physiol 1979, 46:599-602.

17. Severinghaus JW: $A$ combined transcutaneous $\mathrm{PO}_{2}-\mathrm{PCO}_{2}$ electrode with electrochemical $\mathrm{HCO}_{3}^{-}$stabilization. J Appl Physiol 1981, 51:1027-1032.

18. Severinghaus JW, Naifeh $\mathrm{KH}$ : Accuracy of response of six pulse oximeters to profound brief steady hypoxia. Anesthesiology 1987, 67:551-558.

19. Astrup P, Severinghaus JW: The History of Blood Gases, Acids and Bases. Copenhagen: Munksgaard; 1986:332.

20. Severinghaus JW: Historical development of oxygenation monitoring. In Pulse Oximetry. Edited by Payne JP, Severinghaus JW. Berlin: Springer; 1986:1-18.

10.1186/2046-7648-2-29

Cite this article as: Severinghaus: Career perspective: John W.

Severinghaus. Extreme Physiology \& Medicine 2013, 2:29

\section{Submit your next manuscript to BioMed Central and take full advantage of:}

- Convenient online submission

- Thorough peer review

- No space constraints or color figure charges

- Immediate publication on acceptance

- Inclusion in PubMed, CAS, Scopus and Google Scholar

- Research which is freely available for redistribution 